\title{
Activin B induces human endometrial cancer cell adhesion, migration and invasion by up-regulating integrin $\beta 3$ via SMAD2/3 signaling
}

\author{
Siyuan Xiong ${ }^{1}$, Christian Klausen ${ }^{1}$, Jung-Chien Cheng ${ }^{1}$, Hua Zhu ${ }^{1}$ and Peter C.K. \\ Leung $^{1}$ \\ ${ }^{1}$ Department of Obstetrics and Gynaecology, Child and Family Research Institute, University of British Columbia, Vancouver, \\ British Columbia, Canada \\ Correspondence to: Peter C.K. Leung, email: peter.leung@ubc.ca \\ Keywords: activin $B$, inhibin subunit $\beta B$, integrin $\beta 3$, integrin av, serous endometrial cancer \\ Received: June 29, $2015 \quad$ Accepted: August 09, $2015 \quad$ Published: August 28, 2015
}

This is an open-access article distributed under the terms of the Creative Commons Attribution License, which permits unrestricted use, distribution, and reproduction in any medium, provided the original author and source are credited.

\section{ABSTRACT}

Endometrial cancer is the fourth most common female cancer and the most common gynecological malignancy. Although it comprises only $\sim 10 \%$ of all endometrial cancers, the serous histological subtype accounts for $\sim 40 \%$ of deaths due to its aggressive behavior and propensity to metastasize. Histopathological studies suggest that elevated expression of activin/inhibin $\beta B$ subunit is associated with reduced survival in non-endometrioid endometrial cancers (type II, mostly serous). However, little is known about the specific roles and mechanisms of activin $B$ ( $\beta B$ dimer) in serous endometrial cancer growth and progression. In the present study, we examined the biological functions of activin B in type II endometrial cancer cell lines, HEC-1B and KLE. Our results demonstrate that treatment with activin B increases cell migration, invasion and adhesion to vitronectin, but does not affect cell viability. Moreover, we show that activin B treatment increases integrin $\beta 3$ mRNA and protein levels via SMAD2/3-SMAD4 signaling. Importantly, siRNA knockdown studies revealed that integrin $\beta 3$ is required for basal and activin B-induced cell migration, invasion and adhesion. Our results suggest that activin B-SMAD2/3-integrin $\beta 3$ signaling could contribute to poor patient survival by promoting the invasion and/or metastasis of type II endometrial cancers.

\section{INTRODUCTION}

Endometrial cancer is the most common, and second most lethal, gynecological malignancy and the fourth most common female cancer in North America [1]. Traditionally, endometrial cancers have been broadly classified into two clinicopathological types [2]. Accounting for $\sim 70 \%$ of endometrial cancers, type I tumors are primarily comprised of low-grade endometrioid carcinomas associated with unopposed estrogen and favorable prognosis. In contrast, type II endometrial cancers are predominantly non-endometrioid (serous and clear cell) carcinomas associated with advanced stage and poor survival [3, 4]. In particular, despite accounting for only $\sim 10 \%$ of all endometrial cancers, serous endometrial carcinomas account for $\sim 40 \%$ of deaths due to their high grade, deep myometrial invasion and propensity for extrauterine spread $[3,5]$. In The Cancer Genome Atlas's recent genomic characterization of endometrial carcinomas, serous tumors and $\sim 25 \%$ of high-grade endometrioid tumors were grouped in a novel genomic class (copy-number high, serous-like) characterized by extensive copy number alterations, frequent TP53 mutations, and poor outcome [6].

Activins are disulfide-linked homodimers of inhibin $\beta$ subunits which belong to the transforming growth factor-beta (TGF- $\beta$ ) superfamily [7]. The primary isoforms of activins are activin $A(\beta A \beta A)$, activin $A B$ $(\beta \mathrm{A} \beta \mathrm{B})$ and activin $\mathrm{B}(\beta \mathrm{B} \beta \mathrm{B})$. Activins are expressed in many reproductive tissues, including the endometrium, where they regulate numerous biological functions in an autocrine/paracrine manner [8]. In humans, transcripts encoding inhibin $\beta \mathrm{A}$ and $\beta \mathrm{B}$ subunits as well as activin receptors have been detected in primary cultures of 
normal endometrial epithelial and stromal cells [9]. At the protein level, secreted activin A has been detected in conditioned medium from normal endometrial epithelial and stromal cells [9], and immunohistochemical analyses have confirmed endometrial expression of inhibin $\beta \mathrm{A}$ and $\beta B$ subunits throughout the human menstrual cycle [10].

Additionally, increasing evidence suggests that activins and their receptors may participate, either positively or negatively, in the development or progression of a variety of endocrine-related cancers [11]. In endometrial cancer, early studies demonstrated inhibin $\beta$ subunit expression, activin secretion and activin receptor expression in neoplastic endometrial tissues and/or endometrial cancer cell lines $[9,12,13]$. Histopathological studies have since examined the expression of inhibin $\beta \mathrm{A}$ and $\beta \mathrm{B}$ subunits in sizeable cohorts of endometrial carcinomas of either endometrioid [14, 15] or nonendometrioid [16] histology. In endometrioid tumors, positive immunostaining for inhibin $\beta \mathrm{A}$ or $\beta \mathrm{B}$ was correlated with higher grade, though neither subunit was associated with overall, progression free or cause specific survival $[14,15]$. In contrast, non-endometrioid tumors ( $\sim 70 \%$ serous) more frequently displayed positive immunostaining for inhibin $\beta \mathrm{A}$ or $\beta \mathrm{B}$ [15]; however, only elevated inhibin $\beta B$ was associated with reduced cause specific survival [16]. Interestingly, double immunofluorescence staining of endometrioid tumors showed marked co-localization of inhibin $\alpha$ and $\beta A$ subunits (suggesting production of inhibin A), whereas there was minimal co-localization of inhibin $\alpha$ and $\beta B$, suggesting production of activin B [17].

Though histopathological studies suggest activin B may be linked to poor survival in the most lethal subtype of endometrial cancer, few studies have examined the effects of activins on endometrial cancer cells, and all have examined only the effects of activin A. Early studies demonstrated both pro- and anti-proliferative effects of activin A on HEC-50 and ISH endometrial cancer cells, respectively [13]. However, subsequent studies with HEC-1, HHUA and Ishikawa endometrial cancer cells failed to show any effects of activin A on cell proliferation $[12,18]$. In the present study, we examined the effects of activin B on endometrial cancer cell proliferation, migration, invasion and adhesion. We show that activin $B$ does not affect the viability of HEC-1B and KLE type II endometrial cancer cells. However, our results reveal an important role for activin B in promoting HEC-1B and KLE cell migration, invasion and adhesion to vitronectin. In addition, we show that the effects of activin B on cell migration, invasion and adhesion to vitronectin are mediated by the SMAD2/3-SMAD4-dependent upregulation of integrin $\beta 3$. Our findings suggest that activin B signaling could promote the invasion and/or metastasis of type II endometrial cancers, thereby contributing to poor patient survival.

\section{RESULTS}

\section{Activin B increases endometrial cancer cell migration, invasion and adhesion}

In a previous study of 41 non-endometrioid tumors (29 serous, 7 clear cell and 5 undifferentiated), positive immunostaining for inhibin $\beta \mathrm{B}$ was observed in approximately half of the cases and was associated with reduced cause specific survival $(P=0.026)$ and trends towards reduced progression free $(P=0.111)$ and overall ( $P=0.166)$ survival [16]. Similarly, Kaplan-Meier analysis of endometrial cancers with serous histology from The Cancer Genome Atlas (TCGA) ([6]; $n=53$ ) shows that samples with inhibin $\beta B$ mRNA levels greater than the median are associated with reduced disease free survival (Log-rank $P=0.021$, Supplementary Figure 1A) and a trend towards reduced overall survival (Log-rank $P=0.094$, Supplementary Figure 1B). Together, these studies suggest that activin $\mathrm{B}(\beta \mathrm{B}$ dimer) signaling could contribute to poor survival in type II serous endometrial cancer.

Next, we examined the biological functions of activin $\mathrm{B}$ in two type II endometrial cancer cell lines (HEC-1B and KLE). Transwell migration and Matrigel invasion assay results showed that both HEC-1B and KLE cells exhibited basal levels of cell motility and invasiveness (Figures 1A and 1B). Importantly, treatment with $50 \mathrm{ng} / \mathrm{mL}$ activin B significantly increased cell migration and invasion in both cell lines (Figures 1A and 1B). In addition, we examined the effects of activin $B$ on cell adhesion to different extracellular matrix proteins. As shown in Figure 1C, HEC-1B cell adhesiveness was increased in vitronectin-, fibronectin-, Matrigel- or collagen IV-coated tissue culture plates compared to uncoated plates. Interestingly, treatment with $50 \mathrm{ng} / \mathrm{mL}$ activin B significantly enhanced the adhesion of HEC$1 \mathrm{~B}$ cells to vitronectin, but did not affect adhesion to the other extracellular matrix proteins or uncoated plates (Figure 1C). Similarly, activin B treatment increased the adhesion of KLE cells to vitronectin (Figure 1C). MTT assay was used to investigate if the effects of activin $\mathrm{B}$ on HEC-1B and KLE cell migration, invasion and adhesion could result from changes in cell viability/proliferation. As shown in Figure 1D, treatment with $50 \mathrm{ng} / \mathrm{mL}$ activin B every $24 \mathrm{~h}$ for up to $72 \mathrm{~h}$ did not affect HEC-1B or KLE cell viability.

We also pre-treated HEC-1B and KLE cells with the inhibitor SB431542 to determine whether activin/TGF- $\beta$ type I receptors were required for the biological functions of activin B. As shown in Figure 2, pre-treatment with SB431542 completely abolished the effects of activin B on cell migration, invasion and adhesion to vitronectin. 


\section{Activin B up-regulates integrin $\beta 3$ but not integrin $\boldsymbol{\alpha V}$}

Given that activin B specifically enhanced endometrial cancer cell adhesion to vitronectin, we next examined its effects on the levels of integrin $\alpha v \beta 3$, well known to be a major receptor for vitronectin [19]. As shown in Figure 3A, treatment with activin B for different periods of time did not affect the mRNA levels of integrin $\alpha v$ in HEC-1B or KLE cells. However, activin B treatment for $3 \mathrm{~h}$ significantly up-regulated integrin $\beta 3$ mRNA levels and this effect was still observed after $48 \mathrm{~h}$ of treatment (Figure 3A). Western blot analysis was used to confirm the similar stimulatory effects of activin $\mathrm{B}$ on integrin $\beta 3$ protein levels, and to show that they could be abolished by pre-treatment with SB431542 (Figure 3B).

A

$\underline{H E C-1 B}$

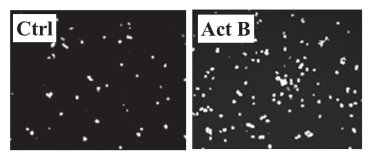

$\underline{\text { KLE }}$
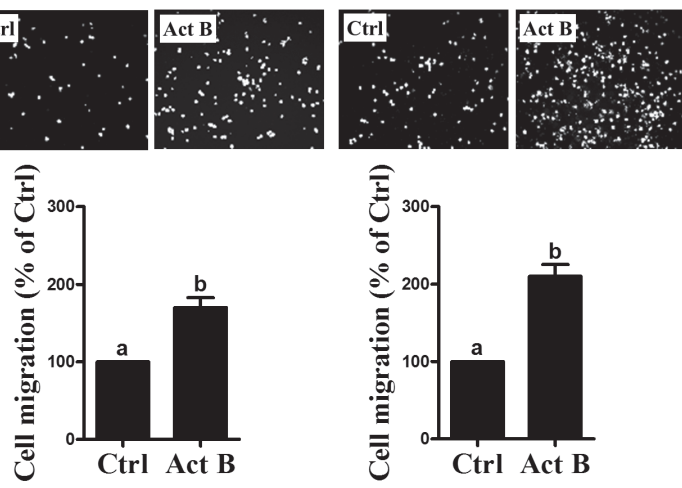

\section{SMAD2/3-SMAD4 signaling is required for the}

up-regulation of integrin $\beta 3$ by activin $B$

To examine the activation of canonical SMAD2/ SMAD3 signaling, HEC-1B and KLE cells were treated with activin $\mathrm{B}$ and Western blot was used to measure the levels of phosphorylated SMAD2 and SMAD3 in relation to their total levels. As shown in Figure 4A, treatment with activin $\mathrm{B}$ for 30 or $60 \mathrm{~min}$ induced the phosphorylation of SMAD2 and SMAD3 in HEC-1B cells, whereas only SMAD2 phosphorylation was increased in KLE cells. Moreover, activin B-induced phosphorylation of SMAD2 and SMAD3 in HEC-1B cells as well as SMAD2 in KLE cells was blocked by pre-treatment with SB431542 (Figure 4B).

Next, we used pre-treatment with siRNA targeting common SMAD4 to investigate the involvement of SMAD

\section{B}

HEC-1B
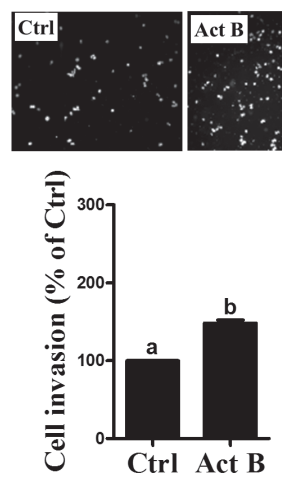

$\underline{\text { KLE }}$
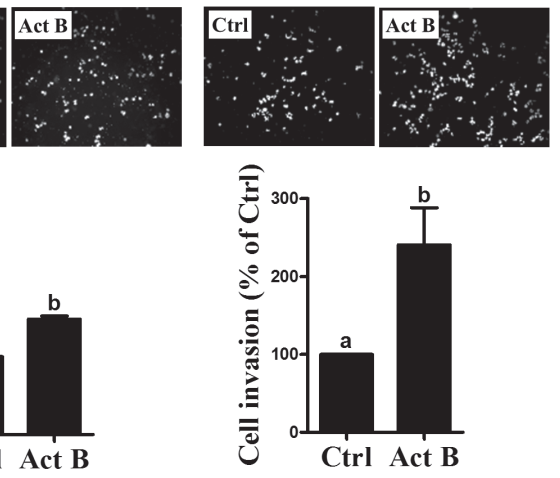

C

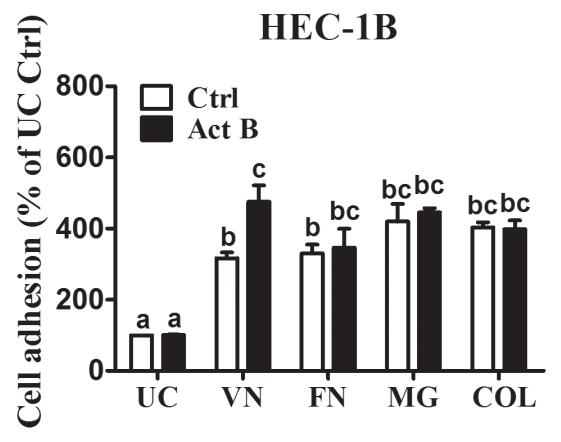

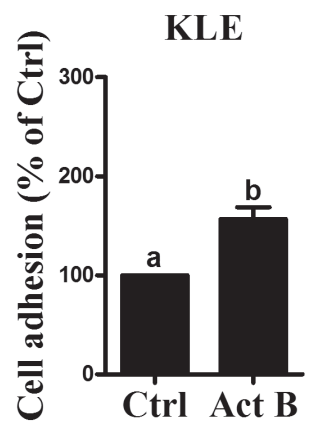

D
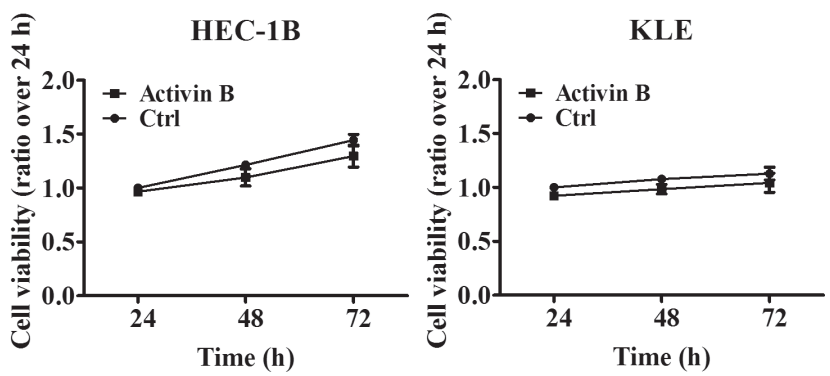

Figure 1: Activin B increases endometrial cancer cell migration, invasion and adhesion. A and B, HEC-1B and KLE cells were treated without (Ctrl) or with $50 \mathrm{ng} / \mathrm{mL}$ activin B (Act B) for $24 \mathrm{~h}$ and then seeded in un-coated A. or Matrigel-coated B. transwell inserts for migration or invasion assays, respectively. Upper panels show representative photomicrographs of migrating/invading cells, while lower panels show summarized quantitative results. C., HEC-1B cells were treated with $50 \mathrm{ng} / \mathrm{mL}$ activin B for $24 \mathrm{~h}$ and then subjected to adhesion assays in un-coated (UC) plates or plates coated with vitronectin (VN), fibronectin (FN), Matrigel (MG) or collagen IV (COL). Additionally, adhesion assays were performed in un-coated or vitronectin-coated plates following treatment of KLE cells with 50 $\mathrm{ng} / \mathrm{mL}$ activin B for $24 \mathrm{~h}$. D., HEC-1B and KLE cells were treated with $50 \mathrm{ng} / \mathrm{mL}$ activin B every $24 \mathrm{~h}$ for up to $72 \mathrm{~h}$ and cell viability was examined by MTT assay. Results are expressed as the mean \pm SEM of at least three independent experiments. Values without a common letter are significantly different $(P<0.05)$. 

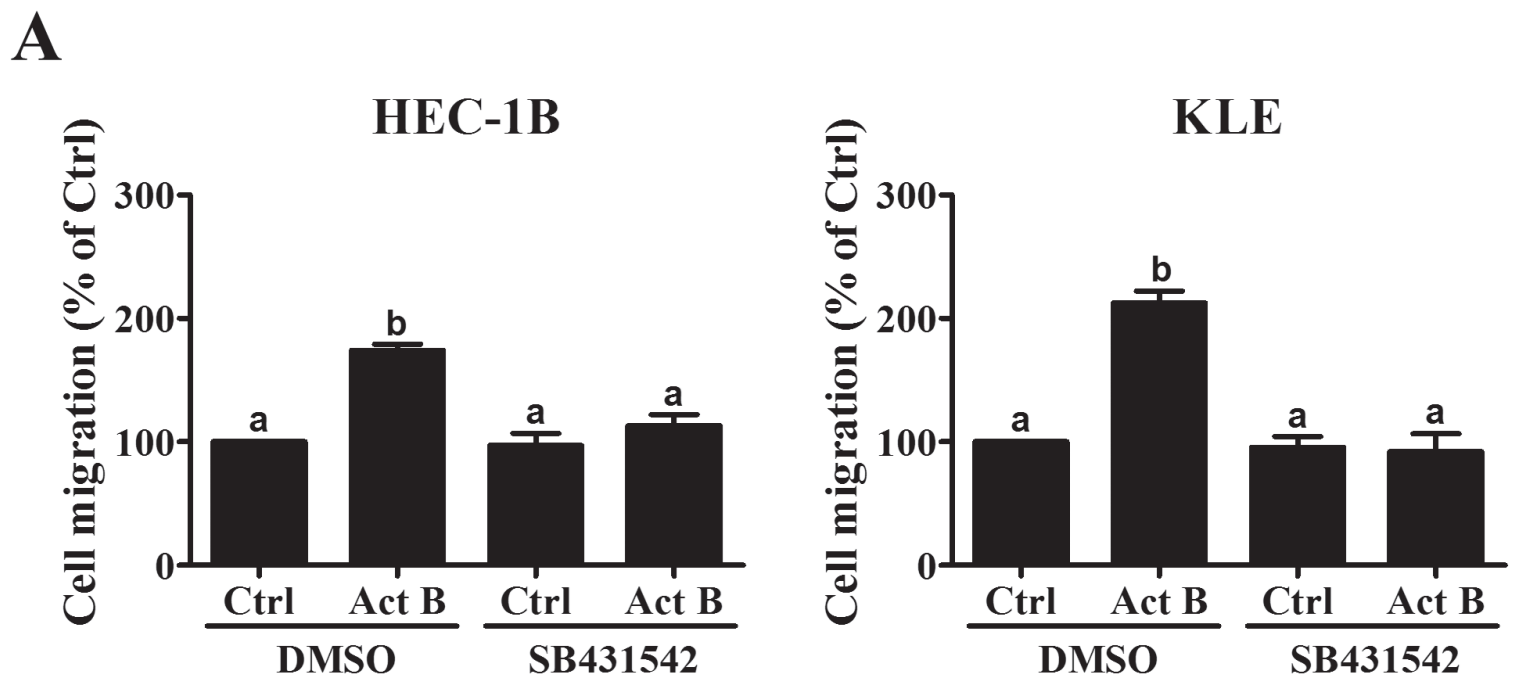

B
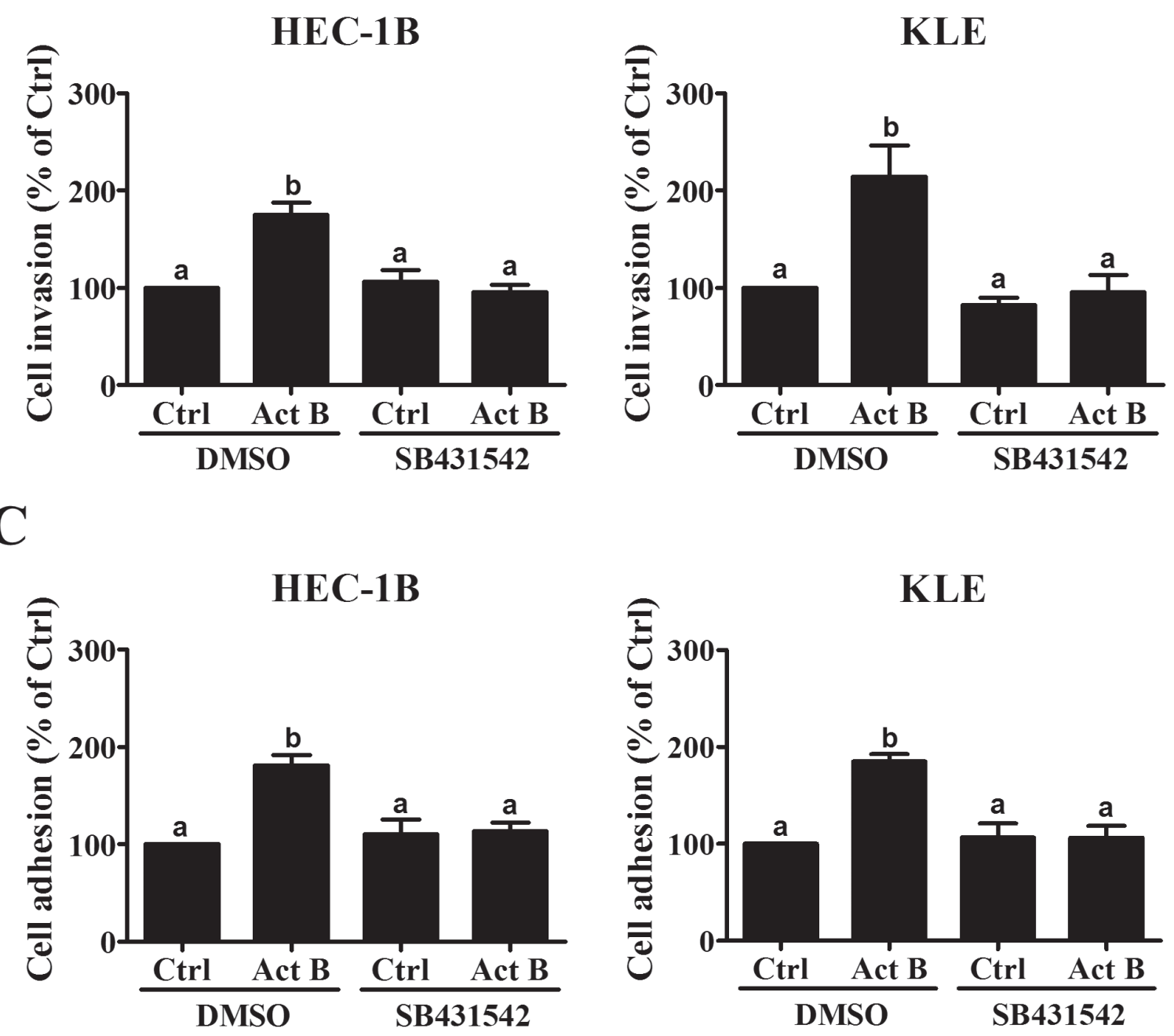

Figure 2: SB431542 abolishes activin B-induced cell migration, invasion and adhesion. Migration A., invasion B. and vitronectin adhesion $\mathbf{C}$. assays were performed with HEC-1B and KLE cells following pre-treatment with vehicle control (DMSO) or SB431542 $(10 \mu \mathrm{M})$ for $1 \mathrm{~h}$ prior to treatment without (Ctrl) or with $50 \mathrm{ng} / \mathrm{mL}$ activin B (Act B) for a further $24 \mathrm{~h}$. Results are expressed as the mean \pm SEM of at least three independent experiments. Values without a common letter are significantly different $(P<0.05)$. 
signaling in the up-regulation of integrin $\beta 3$ by activin $\mathrm{B}$. As shown in Figure 5A, transfection with SMAD4 siRNA significantly reduced endogenous SMAD4 mRNA levels and abolished the up-regulation of integrin $\beta 3$ mRNA by activin B in both HEC-1B and KLE cells. Similarly, Western blot analysis showed that activin B-induced increases in integrin $\beta 3$ protein levels were abolished by pre-treatment of HEC-1B and KLE cells with SMAD4
siRNA (Figure 5B).

SMAD2 and SMAD3 have been shown to mediate TGF- $\beta$-regulated gene expression both redundantly and differentially depending on the cellular context [20]. Therefore, specific siRNAs targeting SMAD2 or SMAD3 were used to investigate their individual roles in the effects of activin $B$ on integrin $\beta 3$ expression in HEC-1B cells. As shown in Figure 6A, transfection with siRNA targeting

A
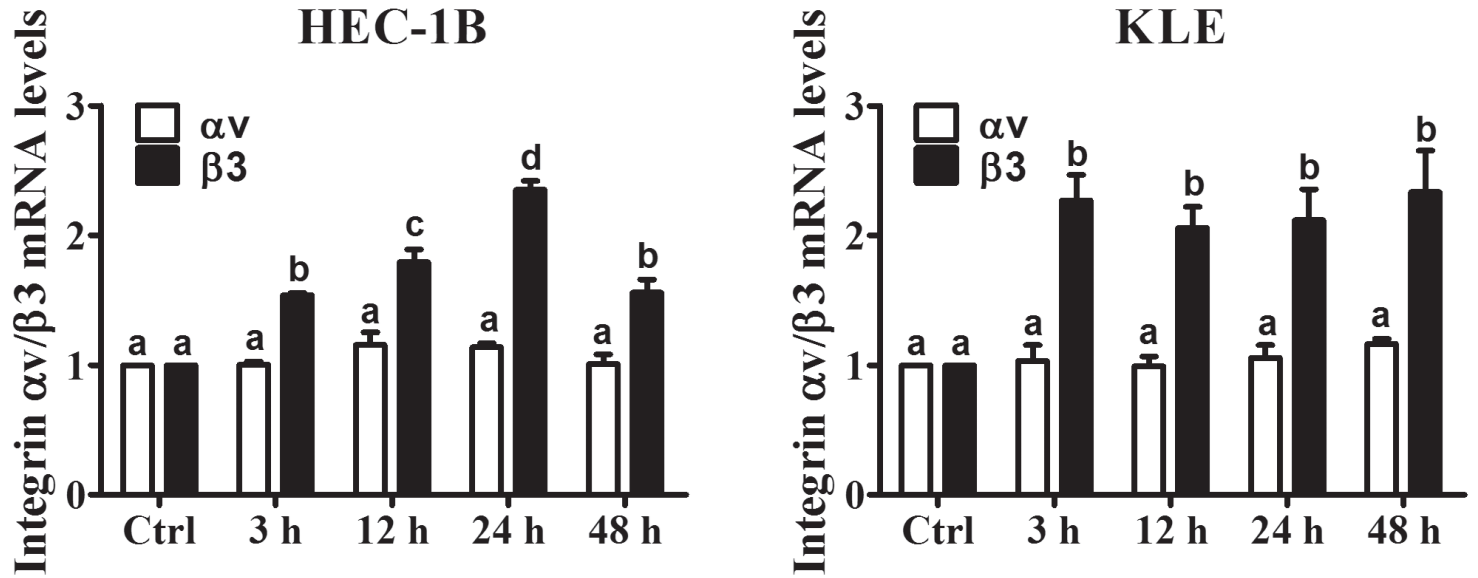

B
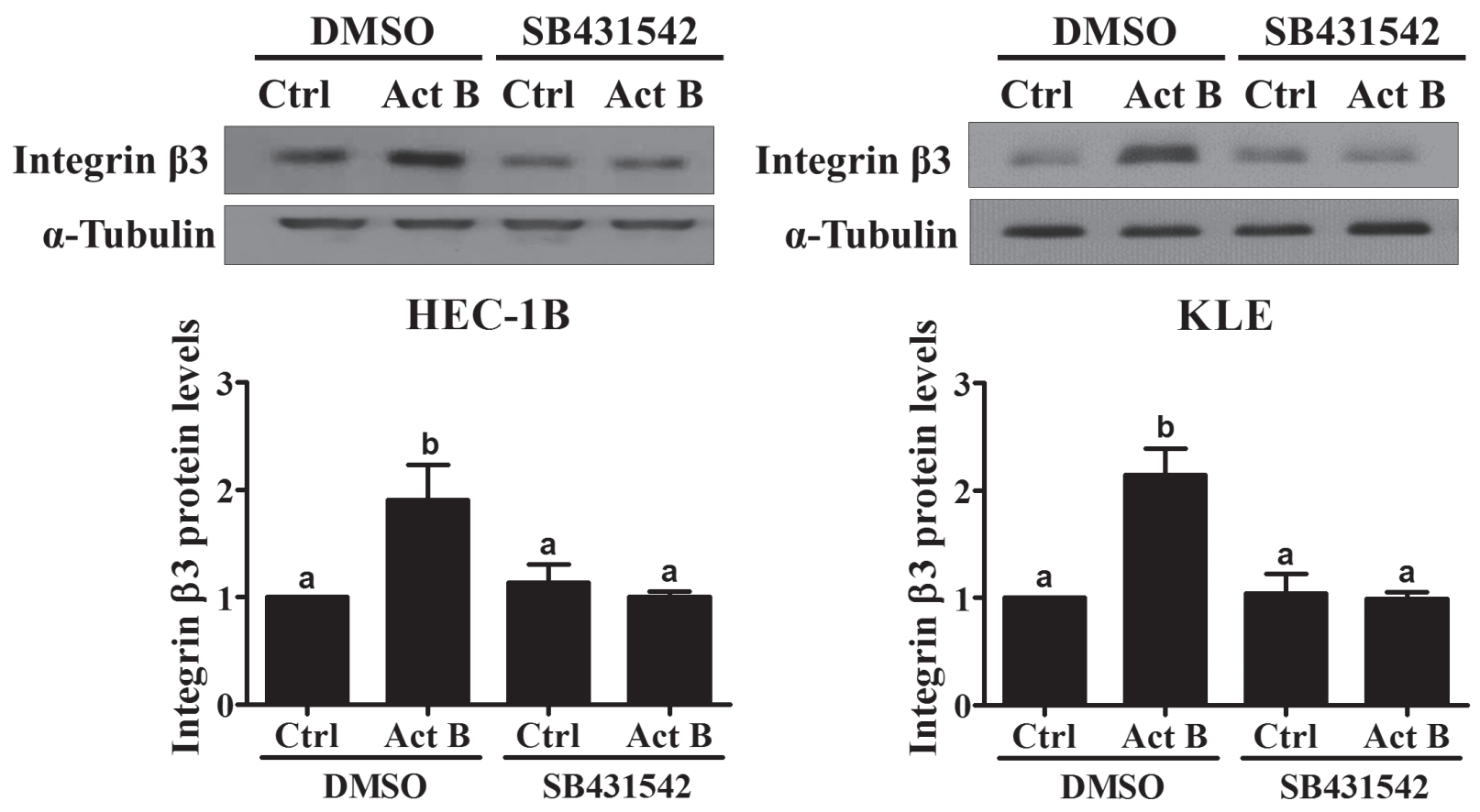

Figure 3: Activin B up-regulates integrin $\boldsymbol{\beta 3}$ expression in endometrial cancer cells. A., HEC-1B and KLE cells were treated for varying times without (Ctrl; time-matched controls displayed as single bar) or with $50 \mathrm{ng} / \mathrm{mL}$ activin $\mathrm{B}$ (Act $\mathrm{B}$ ) and integrin $\alpha \mathrm{v}$ and $\beta 3$ mRNA levels were measured by RT-qPCR. B., HEC-1B and KLE cells were pre-treated with vehicle control (DMSO) or SB431542 (10 $\mu \mathrm{M}$ ) for $1 \mathrm{~h}$ and then treated with $50 \mathrm{ng} / \mathrm{mL}$ activin B for $24 \mathrm{~h}$. Protein levels of integrin $\beta 3$ were examined by Western blot (quantified data are normalized to $\alpha$-tubulin) ting. Results are expressed as the mean \pm SEM of at least three independent experiments. Values without a common letter are significantly different $(P<0.05)$. 
SMAD2 or SMAD3 significantly reduced their respective mRNA levels and abolished the effects of activin $B$ on integrin $\beta 3$ mRNA. Likewise, Western blot analysis showed that activin B-induced increases in integrin $\beta 3$ protein levels were abolished by pre-treatment of HEC$1 \mathrm{~B}$ cells with siRNAs targeting SMAD2 or SMAD3 (Figure 6B). Interestingly, though activin B only increased SMAD2 phosphorylation in KLE cells, its stimulatory effects on integrin $\beta 3 \mathrm{mRNA}$ and protein levels were abolished following pre-treatment of KLE cells with siRNA targeting SMAD2 or SMAD3 (Figure 6).

Integrin $\beta 3$ mediates activin B-induced cell migration, invasion and adhesion to vitronectin

Pre-treatment with siRNA targeting integrin $\beta 3$ was used to investigate its role in activin $\mathrm{B}$-induced

A

$\underline{\text { HEC-1B }}$

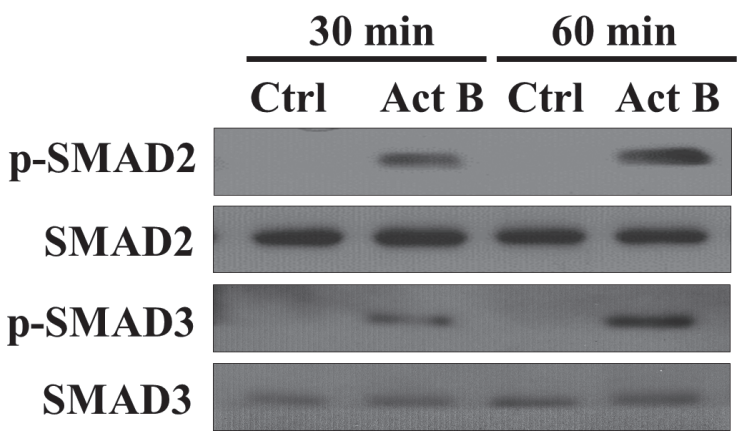

B

\section{HEC-1B}

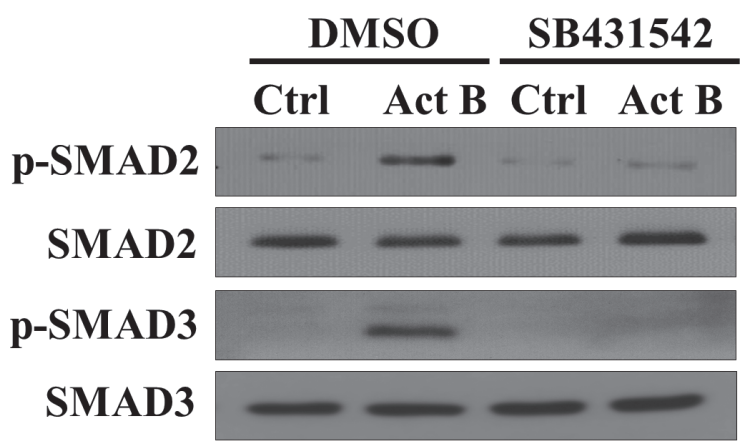

cell migration, invasion and adhesion to vitronectin. As shown in Figure 7A, transfection with integrin $\beta 3$ siRNA significantly down-regulated integrin $\beta 3 \mathrm{mRNA}$ and protein levels in both HEC-1B and KLE cells. Transwell migration and Matrigel invasion assays showed that integrin $\beta 3$ knockdown suppressed the motility and invasiveness of both HEC-1B and KLE cells (Figures 7B and $7 \mathrm{C}$ ). In addition, activin B-induced cell migration and invasion were abolished by pre-treatment with integrin $\beta 3$ siRNA (Figures 7B and 7C). Similarly, integrin $\beta 3$ knockdown reduced both basal and activin $\mathrm{B}$-induced cell adhesion to vitronectin in HEC-1B and KLE cells (Figure 7D).

\section{DISCUSSION}

Previous studies have demonstrated differences between activin $\mathrm{A}$ and activin $\mathrm{B}$ with respect to expression

$\underline{\text { KLE }}$

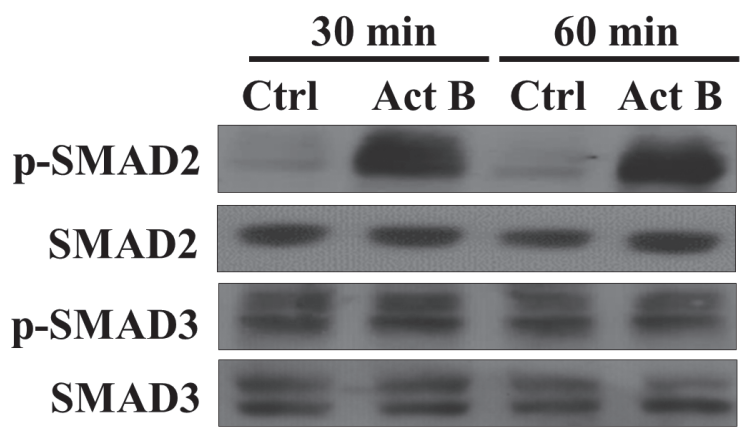

$\underline{\text { KLE }}$

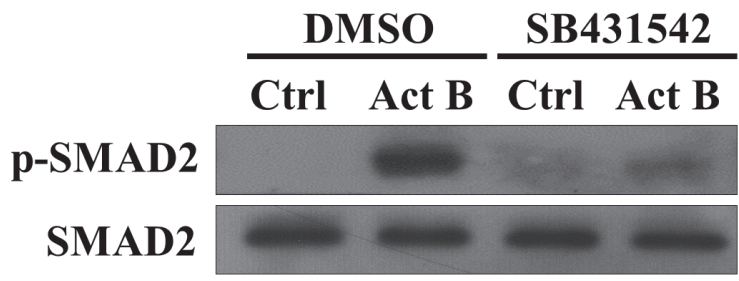

Figure 4: Effects of activin B on SMAD2 and SMAD3 phosphorylation in endometrial cancer cells. A., HEC-1B and KLE cells were treated without (Ctrl) or with $50 \mathrm{ng} / \mathrm{mL}$ activin B (Act B) for 30 or 60 min and Western blot was used to measure the levels of phosphorylated SMAD2 (p-SMAD2) and SMAD3 (p-SMAD3) in relation to their total levels (SMAD2 and SMAD3, respectively). B., HEC-1B and KLE cells were pre-treated with vehicle control (DMSO) or SB431542 $(10 \mu \mathrm{M})$ for $1 \mathrm{~h}$ and then treated with $50 \mathrm{ng} / \mathrm{mL}$ activin B for 60 min. SMAD2 and SMAD3 phosphorylation was examined by Western blot. 
A
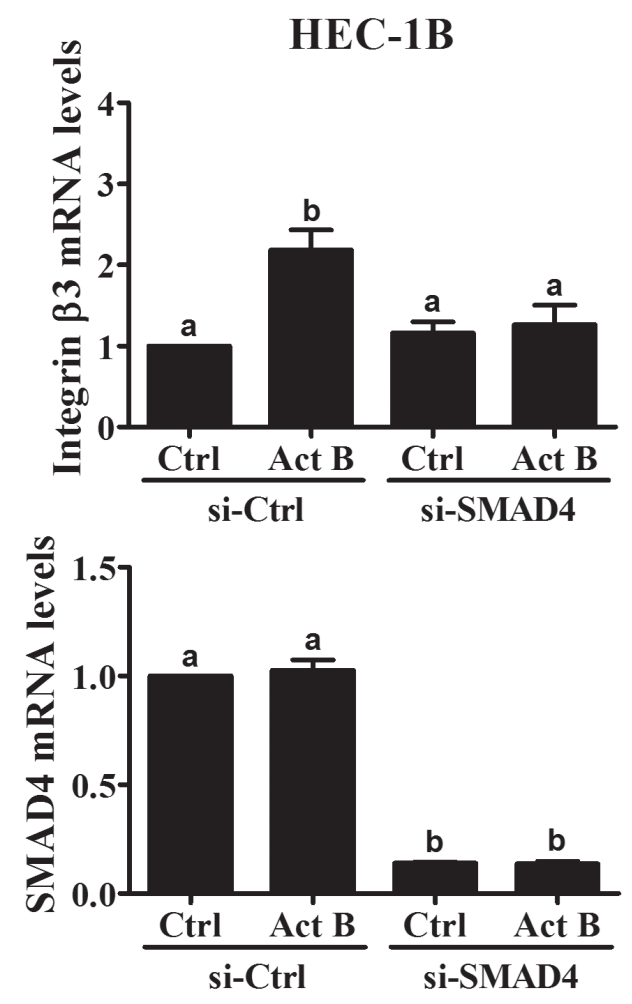

B

\section{$\underline{\text { HEC-1B }}$}
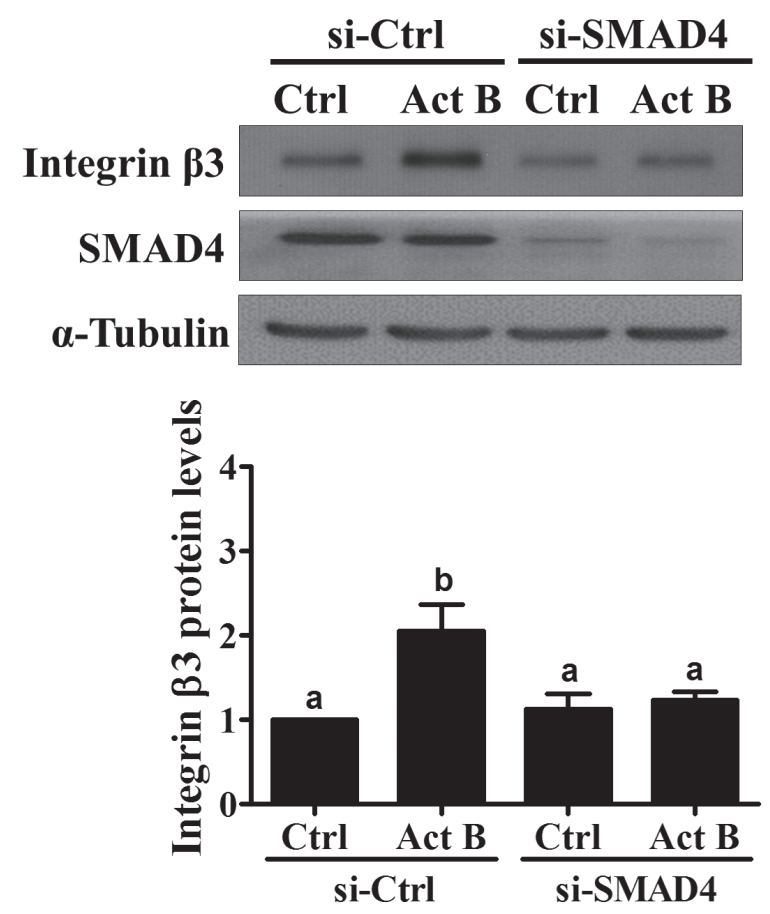
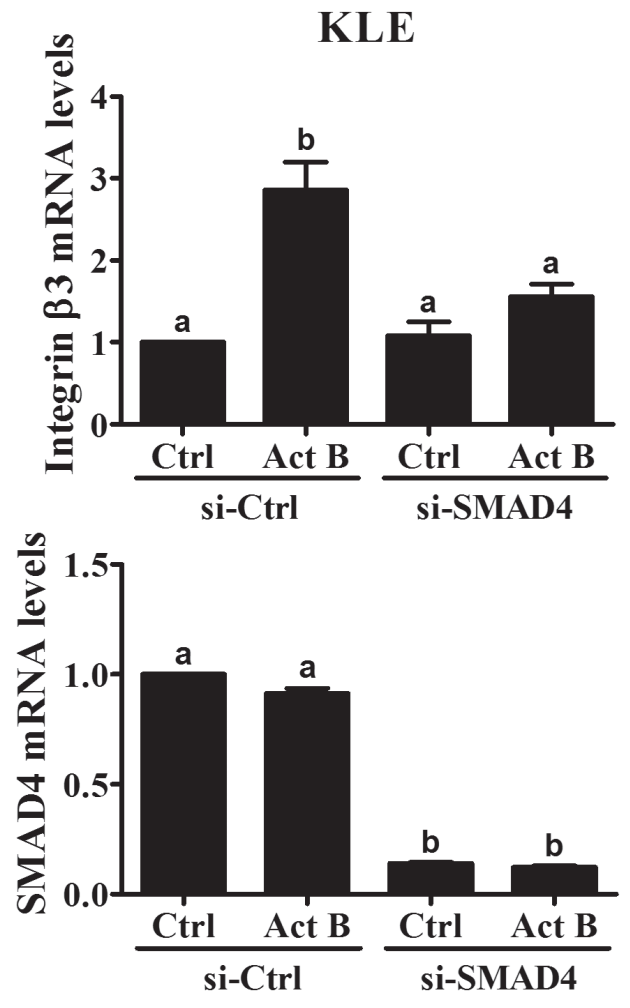

$\underline{\text { KLE }}$
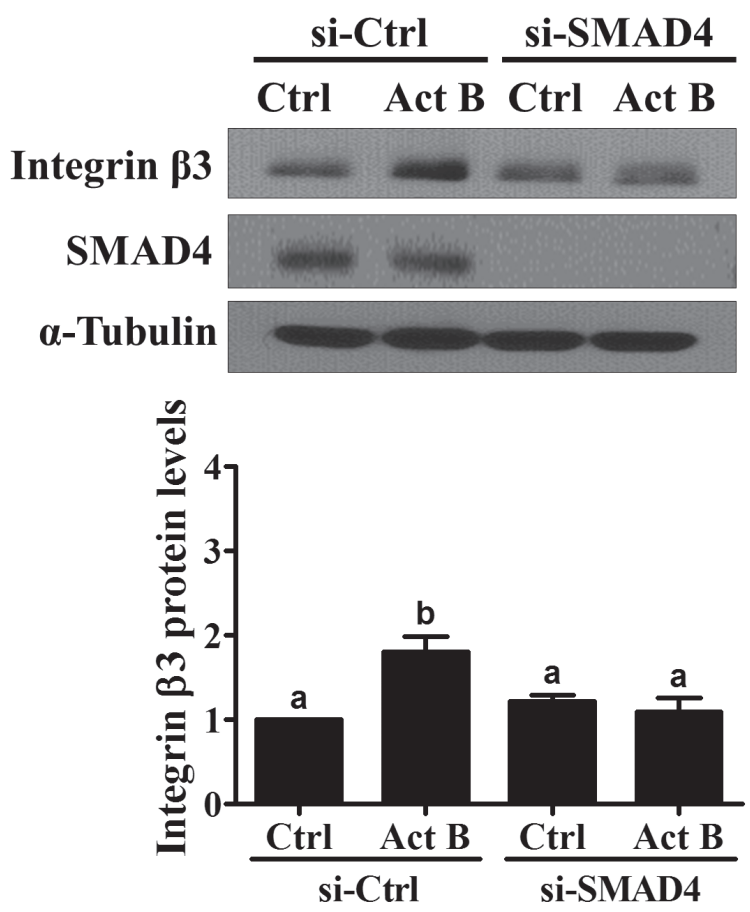

Figure 5: SMAD4 is required for the up-regulation of integrin $\beta 3$ by activin B. HEC-1B and KLE cells were transfected for $48 \mathrm{~h}$ with $20 \mathrm{nM}$ control siRNA (si-Ctrl) or SMAD4 siRNA (si-SMAD4) and then treated without (Ctrl) or with $50 \mathrm{ng} / \mathrm{mL}$ activin B (Act B) for $24 \mathrm{~h}$. Integrin $\beta 3$ and SMAD4 mRNA A. and protein B. levels were measured by RT-qPCR and Western blot, respectively. Results are expressed as the mean \pm SEM of at least three independent experiments. Values without a common letter are significantly different $(P$ $<0.05$ ). 
patterns, receptor/antagonist binding affinities, and biological functions [21-26]. Indeed, inhibin $\beta A$ (Inhba) and $\beta \mathrm{B}(\operatorname{Inh} b b)$ subunit knockout mice exhibit different phenotypes, and the defects observed in Inhba knockout mice are only partially restored by insertion of Inhbb [27, 28]. On the other hand, we have recently demonstrated that recombinant activin $\mathrm{A}, \mathrm{B}$ and $\mathrm{AB}$ have similar effects on human ovarian granulosa cell steroidogenesis and placental trophoblast cell invasion [29, 30]. Taken together, these studies suggest that activin A and B could function distinctly or similarly depending on the cellular context. Our results showing that activin B does not affect endometrial cancer cell viability are in agreement with previous studies examining the proliferative effects of activin A $[12,18]$. However, we cannot definitively rule out potential effects of activin $\mathrm{B}$ on cell proliferation due to the low proliferative rates of HEC-1B and KLE cells and the limited time-course of our studies. Indeed, activin

\section{A}

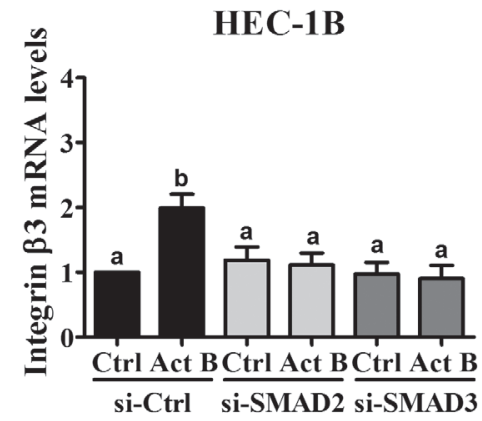

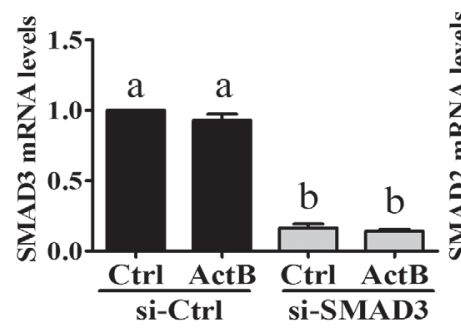
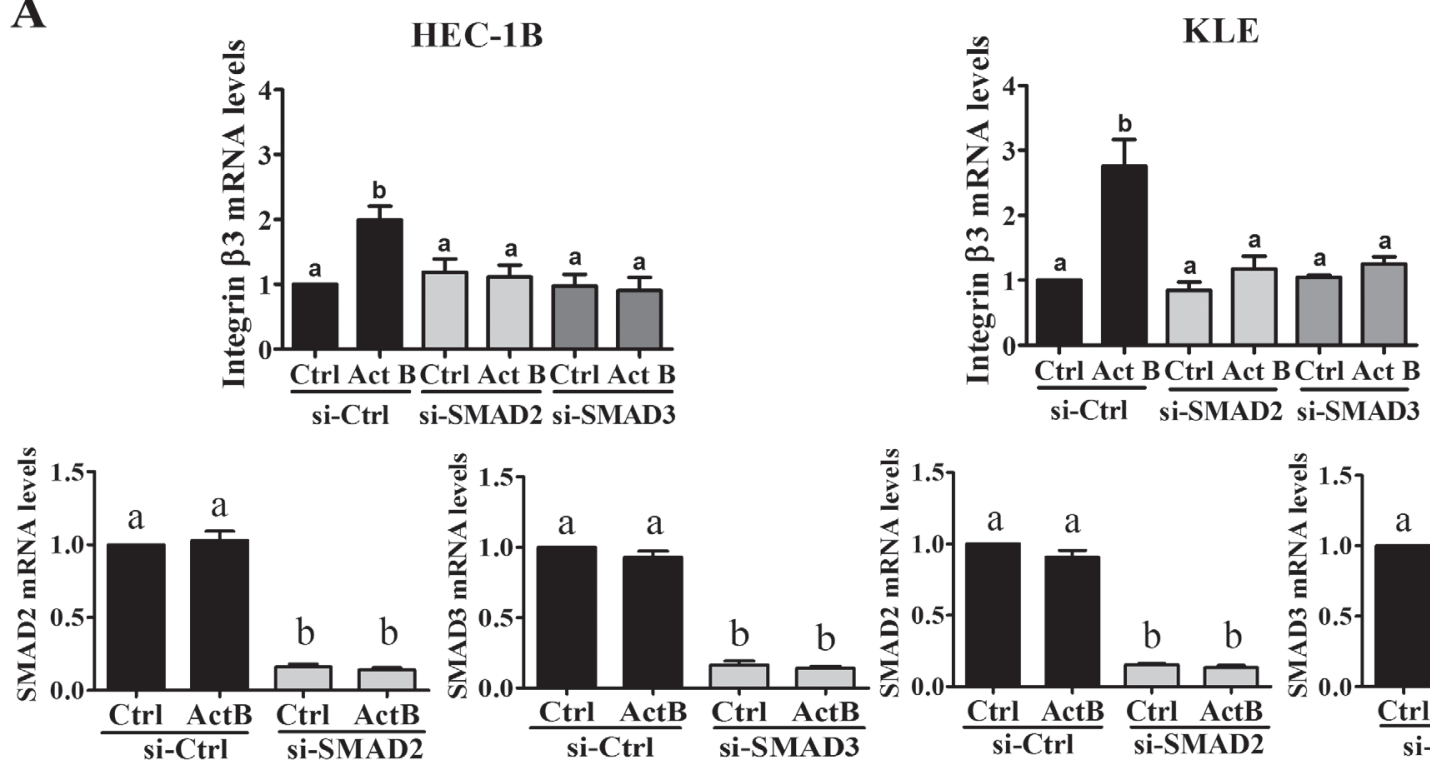

B

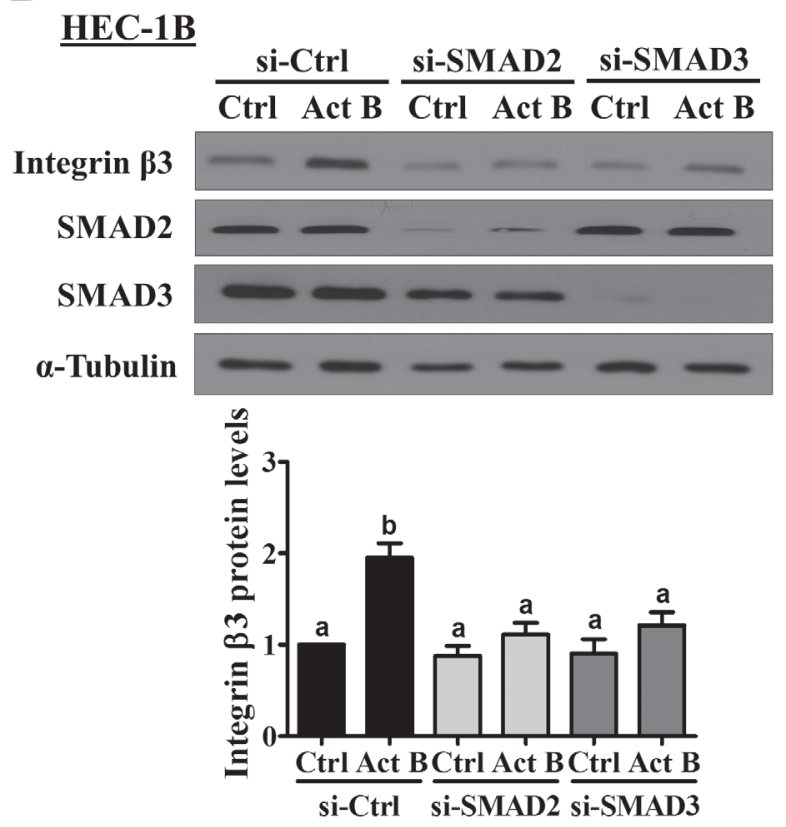

Figure 6: SMAD2 and SMAD3 are required for the up-regulation of integrin $\boldsymbol{\beta 3}$ by activin B. HEC-1B and KLE cells were transfected for $48 \mathrm{~h}$ with $20 \mathrm{nM}$ control siRNA (si-Ctrl), SMAD2 siRNA (si-SMAD2) or SMAD3 siRNA (si-SMAD3) and then treated without (Ctrl) or with $50 \mathrm{ng} / \mathrm{mL}$ activin B (Act B) for $24 \mathrm{~h}$. Integrin $\beta 3$, SMAD2 and SMAD3 mRNA A. and protein B. levels were measured by RT-qPCR and Western blot, respectively. Results are expressed as the mean \pm SEM of at least three independent experiments. Values without a common letter are significantly different $(P<0.05)$. 
A
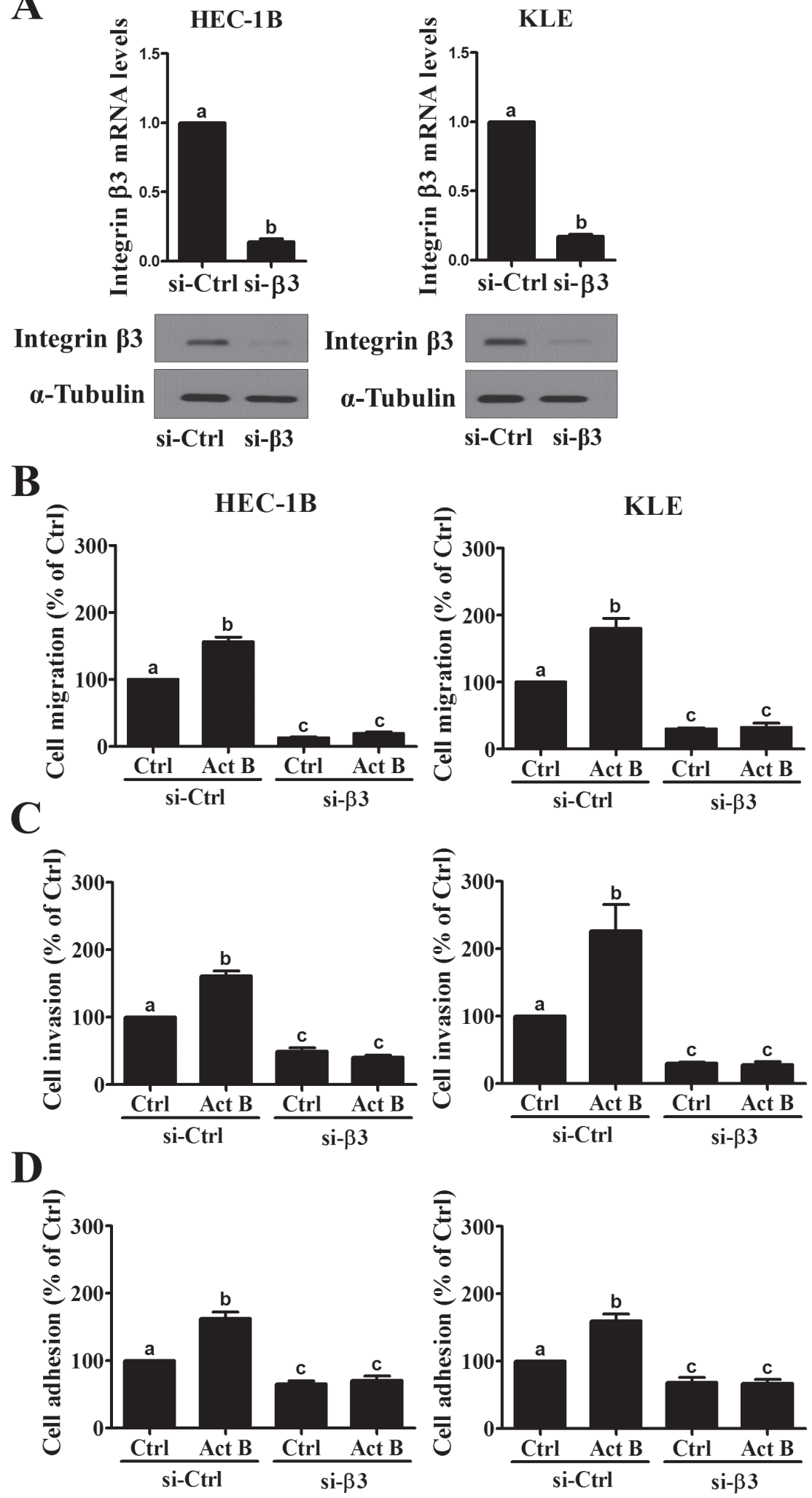

Figure 7: Integrin $\beta 3$ mediates activin $B$-induced endometrial cancer cell migration, invasion and adhesion to vitronectin. A., HEC-1B and KLE cells were transfected for $48 \mathrm{~h}$ with $20 \mathrm{nM}$ control siRNA (si-Ctrl) or integrin $\beta 3$ siRNA (si- $\beta 3$ ) and knockdown efficiencies were examined by RT-qPCR and Western blot. Migration B., invasion C. and vitronectin adhesion D. assays were performed with HEC-1B and KLE cells following transfection with $20 \mathrm{nM}$ control or integrin $\beta 3$ siRNA for $48 \mathrm{~h}$ prior to treatment without (Ctrl) or with $50 \mathrm{ng} / \mathrm{mL}$ activin B (Act B) for a further $24 \mathrm{~h}$. Results are expressed as the mean \pm SEM of at least three independent experiments. Values without a common letter are significantly different $(P<0.05)$. 
A has been shown to inhibit the proliferation of estrogenresponsive ISH endometrial cancer cells, whereas it enhanced the proliferation of estrogen-insensitive HEC50 endometrial cancer cells [13]. Interestingly, treatment with estradiol abolished the suppressive effects of activin A on ISH cell proliferation, whereas it had no impact on the effects of activin A in HEC50 cells [13]. These results suggest that the effects of activins could be modified by other hormones or paracrine factors, perhaps differentially depending on the activin isoform or type I $v s$. type II carcinomas. In renal cancer cells, treatment with activin $\mathrm{B}$ had no effect on proliferation in vitro, however inhibin $\beta B$ subunit knockdown cells formed smaller tumors in xenograft studies [31]. Conversely, activins could differentially modulate the effects of other hormones or paracrine factors. For example, activin A has been shown to reduce the growth inhibitory effects of TGF- $\beta$ on endometrial cancer cell proliferation [18]. Future studies will be required to fully characterize the specific roles and molecular determinants of activin A and B in endometrial cancer cell proliferation.

Commonly confined to the uterus, type I endometrial cancers can often be treated by hysterectomy and have good prognosis. In contrast, the most prevalent type II endometrial cancer, serous endometrial carcinoma, has a relapse rate as high as 50\% [32] and accounts for $40 \%$ of all endometrial cancer related deaths [5]. This lethality is largely due to its propensity for deep invasion and metastatic spread, thus understanding the molecular mechanisms mediating these processes could lead to new therapeutic approaches for type II endometrial cancers. We now demonstrate, for the first time, that treatment with activin B increases type II endometrial cancer cell migration, invasion and adhesion to vitronectin. To date, only a few studies have examined the effects of activin B on cancer cell motility or adhesion. In renal cancer cells, activin $\mathrm{B}$ has been shown to increase cell adhesion and invasion [31, 33], however the molecular mechanisms underlying these effects remain unclear. Together with previous histopathological studies, our results suggest that antagonizing activin B signaling could be a novel approach to the treatment of type II endometrial cancer. However, only a few therapeutic agents targeting the activin system have entered clinical trials (www. clinicaltrials.gov), and none of them are entirely specific for activin signaling [34]. LY-2157299 (Galunisertib) is a small-molecule inhibitor of activin/TGF- $\beta$ type I receptors (related to SB431542) which is currently under phase $1 / 2$ investigation in hepatocellular, pancreatic and glial cancers. Sotatercept (ACE-011) is an activin receptor type IIA (ACVR2A) Fc fusion protein which is currently under phase $1 / 2$ investigation for the treatment of cancer-associated anemia. Interestingly, an ACVR2B Fc fusion protein (STM 434) has entered phase 1 studies in combination with liposomal doxorubicin in patients with ovarian cancer or other advanced tumors, including endometrial cancer (NCT02262455).

Our results show that treatment of endometrial cancer cells with activin $B$ up-regulates integrin $\beta 3$ mRNA and protein levels without altering the expression of integrin $\alpha v$. Integrin $\beta 3$ forms only two $\alpha-\beta$ heterodimers, $\alpha v \beta 3$ and $\alpha \mathrm{IIb} \beta 3$, both of which are receptors for vitronectin [35]. However, integrin $\alpha I I b$ mRNA levels are nearly undetectable in HEC-1B and KLE cells, whereas the mRNA levels of integrin $\alpha v$ are at least 10 times higher than those of integrin $\beta 3$ (data not shown). Thus, our results showing that knockdown of integrin $\beta 3$ reduced both basal and activin B-induced cell migration, invasion and adhesion to vitronectin likely indicate that these effects are mediated by integrin $\alpha v \beta 3$. Integrin $\alpha v \beta 3$ is expressed in many types of cancer where it plays important roles in promoting angiogenesis and cancer cell adhesion, migration and invasion [36-42]. Though studies have shown that integrin $\alpha v \beta 3$ is expressed in endometrioid and serous endometrial cancers $[43,44]$, its clinical and/or therapeutic relevance in these tumors has yet to be defined. Molecular therapies targeting $\alpha v \beta 3$ have achieved positive results such as disease stabilization in advanced solid tumors $[45,46]$, as well as extended survival in high grade glioma $[47,48]$. Interestingly, primary serous endometrial cancer cell migration and adhesion to vitronectin were reduced following treatment with inhibitory anti-integrin $\alpha \mathrm{v}$ antibody [44]. However, endometrial cancers have also been shown to express integrin $\alpha v \beta 5$ and $\alpha v \beta 6[44,49]$, though their functional roles are unknown. Regardless, our study demonstrates that integrin $\beta 3$ (likely $\alpha v \beta 3$ ) may constitute a novel therapeutic target in type II endometrial cancers by virtue of its ability to promote basal and activin B-induced cell adhesion, migration and invasion.

Apart from integrin-mediated cell-matrix contact, the metastatic capacity of tumors is also governed by cadherin mediated cell-cell adhesion [50]. In particular, cancer cell metastasis is often associated with epithelialmesenchymal transition which is characterized by the down-regulation of E-cadherin and up-regulation of $\mathrm{N}$-cadherin [51]. Increasing evidence suggests that endometrial cancers display a number of features associated with the epithelial-mesenchymal transition process [52]. Interestingly, we have recently demonstrated that activin B can stimulate human trophoblast cell invasion by up-regulating $\mathrm{N}$-cadherin expression [30]. Whether modulation of E-cadherin or N-cadherin contributes to activin B-induced cell migration and invasion in endometrial cancer remains unknown and warrants further investigation.

Previous studies have shown that the expression of integrin $\beta 3$ in endometrial cancer cells can be regulated by progesterone [53], macrophage migration inhibitory factor [54], and gonadotropin-releasing hormone [55]. Similar to our results for activin B in endometrial cancer cells, TGF- $\beta 1$ has been shown to up-regulate integrin $\beta 3$ in glioma cells [56], lung fibroblasts [57], and breast 
cancer cells [58], whereas it down-regulated integrin $\beta 3$ in lymphoma cells [59]. Interestingly, our results show that while activin $\mathrm{B}$ activated both SMAD2 and SMAD3 in HEC-1B cells, only SMAD2 was activated in KLE cells. At present, we do not know why activin B failed to increase the levels of phosphorylated SMAD3 in KLE cells. However, it has previously been reported that TGF- $\beta$ isoforms can induce SMAD3 phosphorylation in KLE cells [60], thus it does not appear to be a general defect in SMAD3 phosphorylation. Interestingly, depletion of SMAD3 abolished the stimulatory effects of activin B on integrin $\beta 3$ expression in KLE cells, suggesting that SMAD3 phosphorylation is not required or endogenous levels of SMAD3 phosphorylation are sufficient for activin B-induced integrin $\beta 3$ expression. Regardless, our siRNA results demonstrate that neither SMAD can compensate for the loss of the other, suggesting both SMAD2 and SMAD3 are required for the up-regulation of integrin $\beta 3$ by activin $\mathrm{B}$. Interestingly, knockdown of SMAD3 in lung fibroblasts did not alter TGF- $\beta 1$-induced integrin $\beta 3$ production, whereas it attenuated the up-regulation of integrin $\beta 5$ [57]. Instead, c-Src and p38 MAPK signaling were required for the up-regulation of integrin $\beta 3$ by TGF- $\beta 1$ [57]. Future studies will be required to clarify how SMAD-dependent and -independent signaling is integrated at the level of the ITGB3 promoter.

In summary, our results show that activin B stimulates the migration, invasion and adhesion of type II endometrial cancer cells. Moreover, these effects are mediated by the up-regulation of integrin $\beta 3$ production in a SMAD2/3-SMAD4-dependent manner. Our study identifies novel molecular mechanisms that may contribute to the invasion and/or metastasis of type II endometrial cancers.

\section{MATERIALS AND METHODS}

\section{Cell culture}

HEC1B and KLE type II human endometrial cancer cell lines were purchased from the American Type Culture Collection (Manassas, VA) [61]. HEC-1B cells were cultured in Minimal Essential Medium (Gibco, Life Technologies, Burlington, ON) supplemented with $10 \%$ fetal bovine serum (FBS; Hyclone Laboratories Inc., Logan, UT). KLE cells were cultured in Dulbecco's Modified Eagle Medium/Nutrient Mixture F-12 (Gibco, Life Technologies) supplemented with $10 \%$ fetal bovine serum (FBS; Hyclone Laboratories Inc.). Cultures were maintained at $37^{\circ} \mathrm{C}$ in a humidified atmosphere of $5 \%$ $\mathrm{CO} 2$ in air.

\section{Antibodies and reagents}

Rabbit polyclonal anti-human SMAD4 (\#9515) antibody was obtained from Cell Signaling Technology. The rabbit monoclonal antibodies used in this study were: human phospho-SMAD2 (Ser465/467; 138D4, Cell Signaling Technology), human phospho-SMAD3 (Ser423/425; C25A9, Cell Signaling Technology), and human SMAD3 (C67H9, Cell Signaling Technology). The mouse monoclonal antibodies used were: human SMAD2 (L16D3, Cell Signaling Technology), human integrin $\beta 3$ (\#611141, BD Biosciences), human integrin av (\#611012, BD) and sea urchin $\alpha$-tubulin (B-5-1-2, Santa Cruz). Horseradish peroxidase-conjugated goat anti-mouse IgG and goat anti-rabbit IgG were obtained from Bio-Rad Laboratories (Hercules, CA). SB431542 was purchased from Sigma-Aldrich (Oakville, ON). Recombinant human activin B was obtained from R\&D Systems (Minneapolis, $\mathrm{MN})$.

\section{MTT assay}

MTT (3-(4,5-Dimethylthiazol-2-yl)-2,5diphenyltetrazolium bromide; Sigma) assay was used to determine cell viability. Cells were seeded one day prior to treatment in 24 -well plates $\left(1 \times 10^{4} /\right.$ well) with $500 \mu \mathrm{L}$ of medium and then treated with activin B every $24 \mathrm{~h}$ for up to $72 \mathrm{~h}$. MTT (final concentration of $0.5 \mathrm{mg} / \mathrm{mL}$ ) was added at each time point and incubated for $4 \mathrm{~h}$ prior to removing the medium and adding DMSO to dissolve the crystals. Absorbances were measured at $490 \mathrm{~nm}$ using a microplate spectrophotometer.

\section{Transwell migration and invasion assays}

Migration and invasion assays were performed in Boyden chambers with minor modifications [62]. Cell culture inserts (24-well, pore size $8 \mu \mathrm{m}$; BD Biosciences, Mississauga, ON) were seeded with $1 \times 10^{5}$ cells in 250 $\mu \mathrm{L}$ of medium with $0.1 \%$ FBS. Un-coated inserts were used for migration assays whereas inserts pre-coated with growth factor reduced Matrigel $(40 \mu \mathrm{L}, 1 \mathrm{mg} / \mathrm{mL}$; BD Biosciences) were used for invasion assays. Medium with $10 \%$ FBS $(750 \mu \mathrm{L})$ was added to the lower chamber and served as a chemotactic agent. After incubation for $24 \mathrm{~h}$ (migration) or $48 \mathrm{~h}$ (invasion), non-migrating/invading cells were wiped from the upper side of the membrane and cells on the lower side were fixed in cold methanol and air dried. Cell nuclei were stained with Hoechst 33258 and counted using a Zeiss Axiophot epifluorescent microscope equipped with a digital camera (QImaging, Surrey, BC). Each individual experiment had triplicate inserts and five microscopic fields (obtained from middle, upper, lower, right and left parts of membrane) were counted per insert 
using Northern Eclipse 6.0 software.

\section{Adhesion assays}

96-well plates were coated overnight at $4^{\circ} \mathrm{C}$ with vitronectin $\left(1 \mu \mathrm{g} / \mathrm{cm}^{2}\right.$; R\&D Systems), fibronectin $\left(10 \mu \mathrm{g} / \mathrm{cm}^{2}\right.$; R\&D Systems), Matrigel $\left(5 \mu \mathrm{g} / \mathrm{cm}^{2}\right.$; BD Biosicences) or collagen IV (10 $\mu \mathrm{g} / \mathrm{cm}^{2} ;$ R\&D Systems $)$ and then blocked for $1 \mathrm{~h}$ with $0.5 \%$ bovine serum albumin. Cells were seeded at a density of $4 \times 10^{4}$ cells $/$ well and incubated at $37^{\circ} \mathrm{C}$ for $1.5 \mathrm{~h}$. Non-adherent cells were removed by washing with PBS, and adherent cells were fixed with cold methanol and stained with $0.1 \%$ crystal violet for $25 \mathrm{~min}$ at room temperature. After removing the crystal violet solution, the stained cells were washed with water and $10 \%$ acetic acid was added to dissolve the crystal violet. Absorbances were measured at $590 \mathrm{~nm}$ using a microplate spectrophotometer.

\section{Reverse transcription quantitative real-time PCR (RT-qPCR)}

Total RNA was extracted using TRIzol reagent (Invitrogen, Life Technologies, Burlington, ON) in accordance with the manufacturer's instructions. Reverse transcription was performed with $2 \mu \mathrm{g}$ RNA, random primers and M-MLV reverse transcriptase (Promega, Madison, WI). The primers used for SYBR Green RTqPCR were: integrin $\beta 3,5^{\prime}$-GAA GGC TGG CAG GCA TTG-3' (forward) and 5'-AAT GAT TGT CAC TAC CAA CAT GAC ACT-3' (reverse); integrin $\alpha \mathrm{v}, 5^{\prime}$ TGC CCA GCG CGT CTT C-3' (forward) and 5'-TGG GTG GTG TTT GCT TTG G-3' (reverse); SMAD2, 5'GCC TTT ACA GCT TCT CTG AAC AA-3' (forward) and 5'-ATG TGG CAA TCC TTT TCG AT-3' (reverse); SMAD3, 5'-CCC CAG CAC ATA ATA ACT TGG-3' (forward) and 5'-AGG AGA TGG AGC ACC AGA AG-3' (reverse); SMAD4, 5'-TGG CCC AGG ATC AGT AGG T-3' (forward) and 5'-CAT CAA CAC CAA TTC CAG CA-3' (reverse) and GAPDH, 5'-GAG TCA ACG GAT TTG GTC GT-3' (forward) and 5'- GAC AAG CTT CCC GTT CTC AG-3' (reverse). RT-qPCR was performed using an Applied Biosystems 7300 Real-Time PCR System equipped with 96-well optical reaction plates. The specificity of each assay was validated by melting curve analysis and agarose gel electrophoresis of the PCR products. Assay performance was validated by assessing amplification efficiencies by means of calibration curves, and ensuring that the plot of log input amount versus $\Delta \mathrm{Cq}$ has a slope $<|0.1|$. At least three separate experiments were performed and each sample was assayed in triplicate. A mean value of the triplicates was used for the determination of relative mRNA levels by the comparative $\mathrm{Cq}$ method with GAPDH as the reference gene and using the formula $2^{-\Delta \Delta \mathrm{Cq}}$.

\section{Western blot}

Cells were lysed in ice cold lysis buffer (Cell Signaling Technology) with added protease inhibitor cocktail (Sigma-Aldrich). Extracts were centrifuged at $20,000 \times \mathrm{g}$ for $10 \mathrm{~min}$ at $4^{\circ} \mathrm{C}$ and supernatant protein concentrations were determined using the DC Protein Assay (Bio-Rad Laboratories). Equal amounts of protein $(50 \mu \mathrm{g})$ were separated by SDS polyacrylamide gel electrophoresis and transferred onto PVDF membranes. After blocking for $1 \mathrm{~h}$ with 5\% non-fat dry milk in Trisbuffered saline (TBS), the membranes were incubated overnight at $4{ }^{\circ} \mathrm{C}$ with primary antibodies that were diluted 1000 -fold in 5\% non-fat milk-TBS. Following primary antibody incubation, the membranes were incubated with the appropriate HRP-conjugated secondary antibody. Immunoreactive bands were detected using enhanced chemiluminescent substrate or SuperSignal West Femto chemiluminescent substrate (Thermo Fisher) and X-ray film. Membranes were stripped with stripping buffer (50 $\mathrm{mM}$ Tris- $\mathrm{HCl} \mathrm{pH} \mathrm{7.6,10} \mathrm{mM} \beta$-mercaptoethanol, and 1\% SDS) at $50^{\circ} \mathrm{C}$ for $30 \mathrm{~min}$ and reprobed with anti- $\alpha$-tubulin antibody. Densitometric quantification was performed using Scion Image software (Scion Corp, Frederick, MD) with $\alpha$-tubulin as the internal control for normalization.

\section{Small interfering RNA (siRNA) transfection}

To knock down endogenous integrin $\beta 3$, SMAD2, SMAD3 and SMAD4, forty percent confluent cells were transfected for $48 \mathrm{~h}$ with $20 \mathrm{nM}$ ON-TARGETplus SMART pool siRNA targeting human integrin $\beta 3$, SMAD2, SMAD3 and SMAD4 (Dharmacon, Lafayette, CO) using Lipofectamine RNAiMAX (Invitrogen, Life Technologies). ON-TARGETplus Non-targeting pool siRNA (Dharmacon) was used as the control.

\section{Statistical analysis}

Results are presented as the mean \pm SEM of at least three independent experiments. For experiments involving only two groups, results were analyzed by Two-Sample $t$-test assuming unequal variances using Excel. Multiple group comparisons were analyzed by one-way ANOVA followed by Student-Newman-Keuls test using PRISM software (GraphPad Software). Means were considered significantly different if $P<0.05$ and are indicated by different letters.

\section{ACKNOWLEDGMENTS}

This work was supported by an operating grant from the Canadian Institutes of Health Research to P.C.K.L. S.X. is the recipient of a Four Year Doctoral Fellowship 
from the University of British Columbia.

\section{CONFLICTS OF INTERESTS}

The authors have nothing to disclose

\section{GRANT SUPPORT}

This work was supported by an operating grant from the Canadian Institutes of Health Research to P.C.K.L.

\section{REFERENCES}

1. Siegel RL, Miller KD and Jemal A. Cancer statistics, 2015. CA Cancer J Clin. 2015; 65:5-29.

2. Bokhman JV. Two pathogenetic types of endometrial carcinoma. Gynecol Oncol. 1983; 15:10-17.

3. Murali R, Soslow RA and Weigelt B. Classification of endometrial carcinoma: more than two types. The Lancet Oncology. 2014; 15:e268-278.

4. Di Cristofano A and Ellenson LH. Endometrial carcinoma. Annual review of pathology. 2007; 2:57-85.

5. Hamilton CA, Cheung MK, Osann K, Chen L, Teng NN, Longacre TA, Powell MA, Hendrickson MR, Kapp DS and Chan JK. Uterine papillary serous and clear cell carcinomas predict for poorer survival compared to grade 3 endometrioid corpus cancers. Br J Cancer. 2006; 94:642646.

6. Cancer Genome Atlas Research N, Kandoth C, Schultz N, Cherniack AD, Akbani R, Liu Y, Shen H, Robertson AG, Pashtan I, Shen R, Benz CC, Yau C, Laird PW, Ding L, Zhang W, Mills GB, et al. Integrated genomic characterization of endometrial carcinoma. Nature. 2013; 497:67-73.

7. Xia Y and Schneyer AL. The biology of activin: recent advances in structure, regulation and function. The Journal of endocrinology. 2009; 202:1-12.

8. Ethier JF and Findlay JK. Roles of activin and its signal transduction mechanisms in reproductive tissues. Reproduction. 2001; 121:667-675.

9. Petraglia F, Florio P, Luisi S, Gallo R, Gadducci A, Vigano P, Di Blasio AM, Genazzani AR and Vale W. Expression and secretion of inhibin and activin in normal and neoplastic uterine tissues. High levels of serum activin A in women with endometrial and cervical carcinoma. J Clin Endocrinol Metab. 1998; 83:1194-1200.

10. Jones RL, Salamonsen LA, Critchley HO, Rogers PA, Affandi B and Findlay JK. Inhibin and activin subunits are differentially expressed in endometrial cells and leukocytes during the menstrual cycle, in early pregnancy and in women using progestin-only contraception. Molecular human reproduction. 2000; 6:1107-1117.

11. Risbridger GP, Schmitt JF and Robertson DM. Activins and inhibins in endocrine and other tumors. Endocr Rev. 2001;
22:836-858.

12. Tanaka T, Toujima S, Otani T, Minami S, Yamoto M and Umesaki N. Expression and function of activin receptors in human endometrial adenocarcinoma cells. International journal of oncology. 2003; 23:657-663.

13. Di Simone N, Schneyer AL, Caliandro D, Castellani R and Caruso A. Regulation of endometrial adenocarcinoma cell proliferation by Activin-A and its modulation by 17 betaestradiol. Mol Cell Endocrinol. 2002; 192:187-195.

14. Worbs S, Shabani N, Mayr D, Gingelmaier A, Makrigiannakis A, Kuhn C, Jeschke U, Kupka MS, Friese $\mathrm{K}$ and Mylonas I. Expression of the inhibin/activin subunits (-alpha, -betaA and -betaB) in normal and carcinogenic endometrial tissue: possible immunohistochemical differentiation markers. Oncol Rep. 2007; 17:97-104.

15. Mylonas I, Worbs S, Shabani N, Kuhn C, Kunze S, Schulze S, Dian D, Gingelmaier A, Schindlbeck C, Bruning A, Sommer H, Jeschke U and Friese K. Inhibin-alpha subunit is an independent prognostic parameter in human endometrial carcinomas: analysis of inhibin/activin-alpha, -betaA and -betaB subunits in 302 cases. Eur J Cancer. 2009; 45:1304-1314.

16. Mylonas I. Inhibin-alpha, -betaA and -betaB subunits in uterine non-endometrioid carcinomas: prognostic significance and clinical implications. Eur J Cancer. 2010; 46:2485-2493.

17. Mylonas I, Makovitzky J, Hoeing A, Richter DU, Vogl J, Schulze S, Jeschke U, Briese V and Friese K. Inhibin/ activin subunits beta-A (-beta A) and beta-B (-beta B) are differentially localised in normal, hyperplastic and malignant human endometrial tissue. Acta Histochem. 2006; 108:1-11.

18. Tanaka T, Toujima S and Umesaki N. Activin A inhibits growth-inhibitory signals by TGF-beta 1 in differentiated human endometrial adenocarcinoma cells. Oncol Rep. 2004; 11:875-879.

19. Horton MA. The alpha $\mathrm{v}$ beta 3 integrin "vitronectin receptor". The international journal of biochemistry \& cell biology. 1997; 29:721-725.

20. Brown KA, Pietenpol JA and Moses HL. A tale of two proteins: differential roles and regulation of $\operatorname{Smad} 2$ and Smad3 in TGF-beta signaling. Journal of cellular biochemistry. 2007; 101:9-33.

21. Feijen A, Goumans MJ and van den Eijnden-van Raaij AJ. Expression of activin subunits, activin receptors and follistatin in postimplantation mouse embryos suggests specific developmental functions for different activins. Development. 1994; 120:3621-3637.

22. Tsuchida K, Nakatani M, Yamakawa N, Hashimoto O, Hasegawa $\mathrm{Y}$ and Sugino H. Activin isoforms signal through type I receptor serine/threonine kinase ALK7. Mol Cell Endocrinol. 2004; 220:59-65.

23. Schneyer A, Schoen A, Quigg A and Sidis Y. Differential binding and neutralization of activins $\mathrm{A}$ and $\mathrm{B}$ by 
follistatin and follistatin like-3 (FSTL-3/FSRP/FLRG). Endocrinology. 2003; 144:1671-1674.

24. Niimi S, Horikawa M, Seki T, Ariga T, Kobayashi T and Hayakawa T. Effect of activins AB and B on DNA synthesis stimulated by epidermal growth factor in primary cultured rat hepatocytes. Biological \& pharmaceutical bulletin. 2002; 25:437-440.

25. Niimi S, Hyuga M, Kazama H, Inagawa M, Seki T, Ariga T, Kobayashi T and Hayakawa T. Activins A, AB, and $\mathrm{B}$ inhibit hepatocyte growth factor synthesis by MRC5 human lung fibroblasts. Biological \& pharmaceutical bulletin. 2002; 25:1405-1408.

26. Bertolino P, Holmberg R, Reissmann E, Andersson O, Berggren PO and Ibanez CF. Activin B receptor ALK7 is a negative regulator of pancreatic beta-cell function. Proc Natl Acad Sci U S A. 2008; 105:7246-7251.

27. Chang H, Brown CW and Matzuk MM. Genetic analysis of the mammalian transforming growth factor-beta superfamily. Endocr Rev. 2002; 23:787-823.

28. Brown CW, Houston-Hawkins DE, Woodruff TK and Matzuk MM. Insertion of Inhbb into the Inhba locus rescues the Inhba-null phenotype and reveals new activin functions. Nature genetics. 2000; 25:453-457.

29. Chang HM, Cheng JC, Huang HF, Shi FT and Leung PC. Activin $\mathrm{A}, \mathrm{B}$ and $\mathrm{AB}$ decrease progesterone production by down-regulating StAR in human granulosa cells. Molecular and cellular endocrinology. 2015; 412:290-301.

30. Li Y, Klausen C, Cheng JC, Zhu H and Leung PC. Activin $\mathrm{A}, \mathrm{B}$, and $\mathrm{AB}$ increase human trophoblast cell invasion by up-regulating N-cadherin. J Clin Endocrinol Metab. 2014; 99:E2216-2225.

31. Wacker I, Sachs M, Knaup K, Wiesener M, Weiske J, Huber O, Akcetin Z and Behrens J. Key role for activin $\mathrm{B}$ in cellular transformation after loss of the von HippelLindau tumor suppressor. Molecular and cellular biology. 2009; 29:1707-1718.

32. Acharya S, Hensley ML, Montag AC and Fleming GF. Rare uterine cancers. The Lancet Oncology. 2005; 6:961-971.

33. Wacker I and Behrens J. Activin B Antagonizes RhoA Signaling to Stimulate Mesenchymal Morphology and Invasiveness of Clear Cell Renal Cell Carcinomas. PLoS One. 2014; 9:e111276.

34. Fields SZ, Parshad S, Anne M, Raftopoulos H, Alexander MJ, Sherman ML, Laadem A, Sung V and Terpos E. Activin receptor antagonists for cancer-related anemia and bone disease. Expert opinion on investigational drugs. 2013; 22:87-101.

35. Humphries JD, Byron A and Humphries MJ. Integrin ligands at a glance. J Cell Sci. 2006; 119:3901-3903.

36. Kumar CC. Integrin alpha $v$ beta 3 as a therapeutic target for blocking tumor-induced angiogenesis. Current drug targets. 2003; 4:123-131.

37. Felding-Habermann B, O'Toole TE, Smith JW, Fransvea E, Ruggeri ZM, Ginsberg MH, Hughes PE, Pampori N, Shattil
SJ, Saven A and Mueller BM. Integrin activation controls metastasis in human breast cancer. Proc Natl Acad Sci U S A. 2001; 98:1853-1858.

38. Pecheur I, Peyruchaud O, Serre CM, Guglielmi J, Voland C, Bourre F, Margue C, Cohen-Solal M, Buffet A, Kieffer N and Clezardin P. Integrin alpha(v)beta3 expression confers on tumor cells a greater propensity to metastasize to bone. FASEB J. 2002; 16:1266-1268.

39. Ria R, Vacca A, Ribatti D, Di Raimondo F, Merchionne F and Dammacco F. Alpha(v)beta(3) integrin engagement enhances cell invasiveness in human multiple myeloma. Haematologica. 2002; 87:836-845.

40. Vacca A, Ria R, Presta M, Ribatti D, Iurlaro M, Merchionne F, Tanghetti E and Dammacco F. alpha(v)beta(3) integrin engagement modulates cell adhesion, proliferation, and protease secretion in human lymphoid tumor cells. Experimental hematology. 2001; 29:993-1003.

41. Landen CN, Kim TJ, Lin YG, Merritt WM, Kamat AA, Han LY, Spannuth WA, Nick AM, Jennnings NB, Kinch MS, Tice D and Sood AK. Tumor-selective response to antibody-mediated targeting of alphavbeta3 integrin in ovarian cancer. Neoplasia. 2008; 10:1259-1267.

42. McCabe NP, De S, Vasanji A, Brainard J and Byzova TV. Prostate cancer specific integrin alphavbeta3 modulates bone metastatic growth and tissue remodeling. Oncogene. 2007; 26:6238-6243.

43. Lessey BA, Albelda S, Buck CA, Castelbaum AJ, Yeh I, Kohler M and Berchuck A. Distribution of integrin cell adhesion molecules in endometrial cancer. The American journal of pathology. 1995; 146:717-726.

44. Bellone M, Cocco E, Varughese J, Bellone S, Todeschini P, El-Sahwi K, Carrara L, Guzzo F, Schwartz PE, Rutherford TJ, Pecorelli S, Marshall DJ and Santin AD. Expression of alphaV-integrins in uterine serous papillary carcinomas; implications for targeted therapy with intetumumab (CNTO 95), a fully human antagonist anti-alphaV-integrin antibody. Int J Gynecol Cancer. 2011; 21:1084-1090.

45. Delbaldo C, Raymond E, Vera K, Hammershaimb L, Kaucic K, Lozahic S, Marty M and Faivre S. Phase I and pharmacokinetic study of etaracizumab (Abegrin), a humanized monoclonal antibody against alphavbeta3 integrin receptor, in patients with advanced solid tumors. Investigational new drugs. 2008; 26:35-43.

46. McNeel DG, Eickhoff J, Lee FT, King DM, Alberti D, Thomas JP, Friedl A, Kolesar J, Marnocha R, Volkman J, Zhang J, Hammershaimb L, Zwiebel JA and Wilding G. Phase I trial of a monoclonal antibody specific for alphavbeta3 integrin (MEDI-522) in patients with advanced malignancies, including an assessment of effect on tumor perfusion. Clin Cancer Res. 2005; 11:7851-7860.

47. Goodman SL and Picard M. Integrins as therapeutic targets. Trends in pharmacological sciences. 2012; 33:405-412.

48. Desgrosellier JS and Cheresh DA. Integrins in cancer: biological implications and therapeutic opportunities. 
Nature reviews Cancer. 2010; 10:9-22.

49. Hecht JL, Dolinski BM, Gardner HA, Violette SM and Weinreb PH. Overexpression of the alphavbeta6 integrin in endometrial cancer. Applied immunohistochemistry \& molecular morphology : AIMM / official publication of the Society for Applied Immunohistochemistry. 2008; 16:543547.

50. Canel M, Serrels A, Frame MC and Brunton VG. E-cadherin-integrin crosstalk in cancer invasion and metastasis. J Cell Sci. 2013; 126:393-401.

51. Tsai JH and Yang J. Epithelial-mesenchymal plasticity in carcinoma metastasis. Genes \& development. 2013; 27:2192-2206.

52. Colas E, Pedrola N, Devis L, Ertekin T, Campoy I, Martinez E, Llaurado M, Rigau M, Olivan M, Garcia M, Cabrera S, Gil-Moreno A, Xercavins J, Castellvi J, Garcia A, Ramon y Cajal S, et al. The EMT signaling pathways in endometrial carcinoma. Clinical \& translational oncology : official publication of the Federation of Spanish Oncology Societies and of the National Cancer Institute of Mexico. 2012; 14:715-720.

53. Dai D, Wolf DM, Litman ES, White MJ and Leslie KK. Progesterone inhibits human endometrial cancer cell growth and invasiveness: down-regulation of cellular adhesion molecules through progesterone B receptors. Cancer Res. 2002; 62:881-886.

54. Bondza PK, Metz $\mathrm{CN}$ and Akoum A. Macrophage migration inhibitory factor up-regulates alpha(v)beta(3) integrin and vascular endothelial growth factor expression in endometrial adenocarcinoma cell line Ishikawa. Journal of reproductive immunology. 2008; 77:142-151.

55. Park DW, Choi KC, MacCalman CD and Leung PC. Gonadotropin-releasing hormone (GnRH)-I and GnRH-II induce cell growth inhibition in human endometrial cancer cells: involvement of integrin beta3 and focal adhesion kinase. Reprod Biol Endocrinol. 2009; 7:81.

56. Platten M, Wick W, Wild-Bode C, Aulwurm S, Dichgans J and Weller M. Transforming growth factors beta(1) (TGFbeta(1)) and TGF-beta(2) promote glioma cell migration via Up-regulation of alpha(V)beta(3) integrin expression. Biochem Biophys Res Commun. 2000; 268:607-611.

57. Pechkovsky DV, Scaffidi AK, Hackett TL, Ballard J, Shaheen F, Thompson PJ, Thannickal VJ and Knight DA. Transforming growth factor beta1 induces alphavbeta3 integrin expression in human lung fibroblasts via a beta3 integrin-, c-Src-, and p38 MAPK-dependent pathway. J Biol Chem. 2008; 283:12898-12908.

58. Naber HP, Wiercinska E, Pardali E, van Laar T, Nirmala E, Sundqvist A, van Dam H, van der Horst G, van der Pluijm G, Heckmann B, Danen EH and Ten Dijke P. BMP7 inhibits TGF-beta-induced invasion of breast cancer cells through inhibition of integrin beta(3) expression. Cellular oncology. 2012; 35:19-28.

59. Dou Q, Williams RS and Chegini N. Inhibition of transforming growth factor-beta 1 alters the growth, anchordependent cell aggregation and integrin mRNA expression in human promonocytes: implications for endometriosis and peritoneal adhesion formation. Molecular human reproduction. 1997; 3:383-391.

60. Van Themsche C, Mathieu I, Parent S and Asselin E. Transforming growth factor-beta3 increases the invasiveness of endometrial carcinoma cells through phosphatidylinositol 3-kinase-dependent up-regulation of X-linked inhibitor of apoptosis and protein kinase c-dependent induction of matrix metalloproteinase-9. J Biol Chem. 2007; 282:4794-4802.

61. Korch C, Spillman MA, Jackson TA, Jacobsen BM, Murphy SK, Lessey BA, Jordan VC and Bradford AP. DNA profiling analysis of endometrial and ovarian cell lines reveals misidentification, redundancy and contamination. Gynecol Oncol. 2012; 127:241-248.

62. Woo MM, Salamanca CM, Minor A and Auersperg N. An improved assay to quantitate the invasiveness of cells in modified Boyden chambers. In Vitro Cell Dev Biol Anim. 2007; 43:7-9. 